\section{ETIOLOGY AND OUTCOME OF ACUTE HEPATIC FAILURE - A STUDY OF 40 CASES}

Islam $\mathbf{N}^{1}$, Abdullah $\mathbf{A B M}^{2}$, Zaman $\mathbf{A}^{3}$

\begin{abstract}
:
Acute hepatic failure (ALF) is a medical emergency and infrequently presented in the hospitals and may be associated with high mortality rate. Its etiology shows considerable geographical variations. The viral causes are the most common worldwide, [whilst acetaminophen (Paracetamol) induced hepatotoxicity forms the most common precipitant in many developed countries.]
\end{abstract}

A total forty (40) patients of ALF were studied during the period of January 2003 to July 2004 to evaluate the etiology and outcome. The patients were admitted in different tertiary care hospitals in Bangladesh. The patients were selected randomly by the diagnostic criteria. The selected patients presented with jaundice and hepatic encephalopathy of varying grades. Almost all the cases the causative agents were viruses. Among these, the hepatitis E virus (HEV) was the top most causative agent followed by hepatitis B virus (HBV) in this study. Despite good effort of conservative treatment, the mortality rate was $77.5 \%$. The mortality rate was higher in grade-III and grade-IV encephalopathy patients whereas the prognosis is better in grade-I and grade-II encephalopathy patients.

\section{Introduction}

Acute hepatic failure (ALF) is characterized by the development of hepatic encephalopathy within eight weeks after onset of acute liver disease ${ }^{1}$. There is a wide range of causative agents of ALF with geographical variations, the viruses ranking the top $^{2}$. Besides these, drugs, chemicals, poisonous mushroom, shock, hyper and hypothermia, Budd Chiary syndrome and so on may causes ALF ${ }^{1}$.

Clinical profile of ALF depends upon the causative agents Viral hepatitis is common in Bangladesh. Acute hepatic failure is a frequent complications of acute viral hepatitis. The common viruses that causes hepatitis are hepatitis A virus (HAV), hepatitis B virus (HBV), hepatitis E virus (HEV), hepatitis C virus (HCV), hepatitis delta virus (HDV). All these viruses can cause of acute liver failure. Acute liver failure is characterized by disturbances in consciousness, behaviour and personality changes, fluctuating neurological sign, flapping tremor and disturbances in electroencephalographic change ${ }^{3}$. Altered

1. Professor and Head, Department of Anatomy, Ibn Sina Medical College, Kallyanpur, Dhaka.

2. Associate Professor, Department of Medicine, Bangabandhu Sheikh Mujib Medical University, Dhaka.

3. Medical Officer, Shaheed Ziaur Rahman Medical College Hospital, Bogra. mental status in a jaundice patient is the hallmark of fulminant hepatic failure. Neuropsychiatric changes may develop even before jaundice ${ }^{4}$.

The aim and objective of the present study were to evaluate the etiology and outcome of acute hepatic failure patients admitted in different tertiary care hospitals in our setting. We have given emphasis particularly to search the viral markers and find out the outcome by providing modern facilities for biochemical, haematological and serological investigation as well as medical care.

\section{Materials and Methods}

The study comprises 40 patients with acute hepatic failure. The patients were admitted in different tertiary care hospitals. Among these, twenty four (24) patients from Dhaka Medical College Hospital (DMCH), five (5) patients from Bangabandhu Sheikh Mujib Medical University (BSMMU) and Eleven (11) patients from Jahurul Islam Medical College (JIMCH) were observed during the period of January 2003 to July 2004. The patients were selected randomly on the basis of diagnostic criteria. Chronic hepatitis cases have been excluded in this study by doing serology, USG of abdomen specially hepatobiliary system \& in some cases endoscopic examination of upper gastrointestinal tract. The following criteria were used to diagnose acute hepatic failure ${ }^{5}$.

a. Biochemical and haematological features suggestive of hepatitis (Raised serum bilirubin, raised serum transaminase and prolonged prothrombin time).

b. Hepatic encephalopathy within 8 weeks from the onset of acute hepatitis.

c. No pre-existing liver disease.

The selected patients presented with jaundice and hepatic encephalopathy. The clinical grades of hepatic encephalopathy were done by following ways of "Modified Conn \& Liebeerthal grading system" 4 .

GradeI : Confused, altered mood or behavior, psychometric defects, disordered sleep pattern.

Grade II : Dorwsy, lethargy, inappropriate behaviour, personality change.

Grade III : Stuporous but speaking and obeying simple commands. Inarticulate speech, marked confusion, amnesia \& occasional fits.

Grade IV : Coma.

All the patients were thoroughly investigated biochemically and for viral markers to search for the causes of ALF. The clinical profile and investigations results of each patients were recorded on a predesigned data collection form. All the patients 
were treated conservatively and monitored periodically. The mean duration of observation was four (4) weeks.

\section{Observation and Results}

A total 40 patients were studied on the basis of diagnostic criteria for acute hepatic failure. All the patients presented with mild to severe jaundice and features of hepatic encephalopathy.

In this study, majority of the patients (87.5\%) presented within the $4^{\text {th }}$ weak of illness but only $(17.5 \%)$ patient presented within the $1^{\text {st }}$ weak of illness. The death rate was lower $(42.86 \%)$ in those presented within $1^{\text {st }}$ week but higher (84.85\%) of those presented after $1^{\text {st }}$ week (Table-I).

Seven (17.5\%) patients presented with hepatic encephalopathy of grade-IV and ten (25\%) patients had grade-III encephalopathy. Only two patients from grade-III were survived and rest of the patients from grade-III and all patients from grade-IV hepatic encephalopathy died in this study (Table-II).

Serum bilirubin level, serum alanine aminotransferase (ALT) level, serum albumin level and prothrombin time were measured in all the studied patient. Thirty three $(82.5 \%)$ patients had bilirubin level between $85-340 \mathrm{mmol} / \mathrm{L}$, two (5\%) patient had bilirubin level below $85 \mathrm{mmol} / \mathrm{L}$ and five (12.5\%) patients had bilirubin level above $>340 \mathrm{mmol} / \mathrm{L}$ (Table-III). ALT level was less than $100 \mathrm{U} / \mathrm{L}$ in seven (17.5\%) patients, between 100-1000 $\mathrm{U} / \mathrm{L}$ in thirty two (80\%) patients and only one (2.5\%) patient had ALT level above $1000 \mathrm{U} / \mathrm{L}$ (Table-IV). Twenty one patients (52.5\%) had prothrombin time between 15 -30 seconds and ten patients (25\%) had more than 50 seconds (Table-V). Fourteen (35\%) patients had serum albumin level below $35 \mathrm{gm} / \mathrm{L}$ and the rest twenty six (65\%) patients had above 35 gm/L (Table-V). The mortality rates were $80 \%$ and $90 \%$ of those patients having higher bilirubin level (>340 mmol/L) and prothrombin time (>50 seconds) respectively. The mortality rate was $64 \%$ in those having lower albumin level (<35 gm/L).

Viral markers for hepatitis B, hepatitis C hepatitis E and hepatitis A viruses were done in all cases. Marker for hepatitis B and hepatitis E virus were found positive in fourteen (35\%) and sixteen (40\%) cases respectively. Both hepatitis B and hepatitis E viral markers were positive in eight (20\%) cases. Marker for hepatitis A virus was positive in one case. All viral markers were negative in one (2.5\%) case (Table-VII). Marker for hepatitis D virus could not be done in this study. The causative agent could not be indentified in one case. Inspite of optimum conservative management, thirty one (77.5\%) patients were died and nine (22.5\%) patients were recovered in this study (Table-VIII).
Table-I: Duration of illness and death in patients of acute hepatic failure in this study $(n=40)$.

\begin{tabular}{lccc}
\hline $\begin{array}{l}\text { Duration of } \\
\text { illness (week) }\end{array}$ & $\begin{array}{c}\text { Admitted patients } \\
\text { Number }\end{array}$ & \multicolumn{2}{c}{ Death of patients } \\
Number & Percentage \\
\hline$<1$ & 7 & 3 & 42.85 \\
$1-2$ & 13 & 10 & 76.92 \\
$3-4$ & 15 & 13 & 86.67 \\
$>4$ & 5 & 5 & 100 \\
\hline
\end{tabular}

Table-II:Distribution of grades of hepatic encephalopathy and death in patients of acute hepatic failure in this study $(n=40)$.

\begin{tabular}{lccc}
\hline Grades of hepatic & \multicolumn{2}{c}{ Admitted patients } & \multicolumn{2}{c}{ Death of patients } \\
encephalopathy & Number & Number & Percentage (\%) \\
\hline Grade-I & 8 & 5 & 62.50 \\
Grade-II & 15 & 11 & 73.33 \\
Grade-III & 10 & 8 & 80.00 \\
Grade-IV & 7 & 7 & 100.00 \\
\hline
\end{tabular}

Table-III: Serum bilirubin level in patients of acute hepatic failure at presentation in this study $(n=40)$.

\begin{tabular}{lcc}
\hline $\begin{array}{l}\text { Serum bilirubin level } \\
(\mathrm{mmol} / \mathrm{L})\end{array}$ & $\begin{array}{c}\text { Number of } \\
\text { patients }\end{array}$ & Percentage (\%) \\
\hline$<85$ & 2 & 5.0 \\
$85-170$ & 12 & 30.0 \\
$171-340$ & 21 & 52.5 \\
$341-510$ & 3 & 7.5 \\
$>510$ & 2 & 5.0 \\
\hline
\end{tabular}

Table-IV: Serum alanine aminotransferase level in patients of acute hepatic failure at presentation in this study $(n=40)$.

\begin{tabular}{lcc}
\hline Serum ALT(U/L) & Number of patients & Percentage (\%) \\
\hline$<100$ & 7 & 17.5 \\
$100-300$ & 21 & 52.5 \\
$301-500$ & 8 & 20 \\
$501-1000$ & 3 & 7.5 \\
$>1000$ & 1 & 2.5 \\
\hline
\end{tabular}


Table-V: Prothrombin time in patients of acute hepatic failure at presentation in this study $(n=40)$.

\begin{tabular}{lcc}
\hline $\begin{array}{c}\text { Prothrombin time } \\
\text { (seconds) }\end{array}$ & $\begin{array}{c}\text { Number of } \\
\text { patients }\end{array}$ & $\begin{array}{c}\text { Percentage } \\
(\%)\end{array}$ \\
\hline $15-17$ & 9 & 22.5 \\
$18-30$ & 12 & 30 \\
$31-50$ & 9 & 22.6 \\
$>50$ & 10 & 25 \\
\hline
\end{tabular}

Table-VI:Serum albumin levels in patients of acute hepatic failure at presentation in this study $(n=40)$.

\begin{tabular}{lcc}
\hline $\begin{array}{l}\text { Serum albumin } \\
(\mathrm{gm} / \mathrm{L})\end{array}$ & $\begin{array}{c}\text { Number of } \\
\text { patients }\end{array}$ & $\begin{array}{c}\text { Percentage } \\
(\%)\end{array}$ \\
\hline$<35$ & 14 & 35 \\
$35-45$ & 22 & 55 \\
$>45$ & 4 & 10 \\
\hline
\end{tabular}

Table-VII: Distribution of viral markers in patients of acute hepatic failure in this study $(n=40)$

\begin{tabular}{lcc}
\hline Viral markers & Number of patients & Percentage (\%) \\
\hline HEV (positive) & 14 & 35 \\
HBV (positive) & 16 & 40 \\
Both HEV \& HBV (positive) & 8 & 20 \\
HAV (positive) & 1 & 2.5 \\
All viral markers (negative) & 1 & 2.5 \\
\hline
\end{tabular}

Table-VIII:Outcome of treated patients of acute hepatic failure in this study $(n=40)$.

\begin{tabular}{lcc}
\hline Outcome & Number of patients & Percentage (\%) \\
\hline Recovered & 9 & 22.5 \\
Expired & 31 & 77.5 \\
\hline
\end{tabular}

\section{Discussion}

Acute hepatic failure is a critical condition. This study evaluated the etiology and outcome of acute hepatic failure patients admitted in three medical institutes of Bangladesh.

All the patients investigated thoroughly and also searched for viral markers. All the patients were treated conservatively and monitored periodically.
Varying grades of hepatic encephalopathy is the hallmark of acute hepatic failure in this study. The death rate was lower (70\%) in grade-I and grade-II encephalopathy but higher (89\%) in grade-III and grade-IV encephalopathy. This is similar to other studies. The death rate of patients with grade-III and grade-IV hepatic encephalopathy of those studies were $75.8 \%$ and $81 \%$ respectively ${ }^{6}$.

In this study the mortality rate were higher in those patients having high serum bilirubin level (>340 mmol/L), high prothrombin time ( $>50$ seconds) and less serum albumin $(<35$ $\mathrm{gm} / \mathrm{L})$. The total number of these groups of patients were 5,10 and 14 and the mortality rates were 80\%(5), 90\%(9) and 64\%(9) respectively. These findings are closely related to other studies. They reported more than $90 \%$ death in case of high serum bilirubin and prothrombin time ${ }^{7}$.

Viral markers were done in all the patients in this study. Hepatitis E virus was positive in sixteen (40\%) cases and hepatitis B in fourteen (35\%) cases. Co-infection with hepatitis B and hepatitis E viruses were positive in eight (20\%) patients. Report from developing countries showed that HEV is the main cause of acute hepatic failure which is lower in western countries 8,9 . A study from UK reported only $16.6 \%$ cases of acute hepatic failure due to HEV infection but a study from India reported $62 \%$ cases $^{8}$. HBV causes acute hepatic failure in $30-40 \%$ cases in western countries ${ }^{10,11}$. In two other studies reported $40 \%$ and $28.5 \%$ cases of acute hepatic failure were due to HBV infection ${ }^{12,13}$. Data is not available about the co-infection with $\mathrm{HBV}$ and $\mathrm{HEV}$ in acute hepatic failure ${ }^{8}$. Hepatitis A virus was positive in one (2.5\%) case and the causative agent could not be identified in only one case in this study. A study reported that hepatitis A virus infection complicating acute liver failure was less than $1 \%$ case $^{12}$. In USA about one third of adult have Anti HAV antibodies and about 100 death per year are attributed to HAV related acute liver failure ${ }^{14}$.

By providing optimum conservative management, the survival rate in patients of acute hepatic failure in this study was $22.5 \%$. This was almost similar to other studies ${ }^{4}$. Survival rate was higher (57.14\%) in patient admitted within $1^{\text {st }}$ week of illness and lower (15.15\%) in those admitted after $1^{\text {st }}$ week. This is also similar to other studies. The survival rate were $53.3 \%$ and $14.9 \%$ in patients admitted within $1^{\text {st }}$ week and after $1^{\text {st }}$ week of illness respectively in those studies ${ }^{15,16}$.

\section{Summary \& Conclusion}

Clinical and biochemical profile of 40 patients with acute hepatic failure were studied. The patients were admitted in three tertiary care hospitals. Features of hepatitis, encephalopathy and increased prothrombin time in the absence of any features suggestive of pre-existing liver diseases were the key indicators 
for the diagnosis of acute hepatic failure. All patients had jaundice and features of encephalopathy ranging from gradeI to grade-IV. All the patients were thoroughly investigated and provided optimum conservative management and monitored periodically.

Raised prothrombin time, serum bilirubin and alanine aminotransferase were found in all patients. Serum albumin was slightly low in 35\% patients. Anti HEV was positive in $40 \%$ patients and HBsAg positive in 35\% patients. Both anti $\mathrm{HEV}$ and HBsAg were positive in $20 \%$ of patients. HAV was positive in only one case in this study. Causes could not be identified in one case. Only $22.5 \%$ a patients were recovered completely and $77.5 \%$ patients expired. The mortality rates were higher with those patients presented after $1^{\text {st }}$ week of illness, with hepatic encephalopathy grade-III and grade-IV, very high serum bilirubin, high prothrombin time and less serum albumin. Although there are some minute variations in some parameters, most of the findings in the present study are similar as suggested by other authors. However further study with larger samples, with improved investigations and management techniques is suggested to evaluate the strength or weakness of this study.

\section{References}

1. Friedman LS. Liver, biliary tract \& pancreatic disease. In: Tierny LM, Stephen Jr, Macphee J. Rapadakis MA. Current Medical Diagnosis \& treatment. $42^{\text {nd }}$ ed. New York: McGraw Hill, 2003; 631-642.

2. Bernal W, Wendon S. Acute liver failure; clinical features and management. Eu J Gastroentrol Hepatol, 1999; 11:9.

3. Chang RT, Podolsky DK. Cirrhosis \& its complications. In: Braunwald E, Fauci AS, Kasper DL et al. Harrison's principles of internal medicine $15^{\text {th }}$ ed. vol-2; New York: McGraw Hill 2001; 1756-1766.

4. Sherlock S, Dooley S. Diseases of the liver \& biliary system. $11^{\text {th }}$ ed. Oxford; Blackwell Science 2002; 111-121.

5. Hyes PC, Simpson KS, Garden OS. Liver \& biliary tract diseases. In: Harlett C, Chilvers ER, Boon NA, Colledge NR, Hunten SA editors. Davidson's Pinciples and Practice

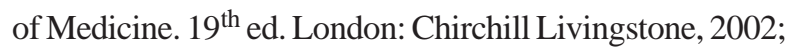
355-361.

6. Rake N, Pannel G, Flute PT. Intravascular coagulation in hepatic necrosis. Lancet 1979; 1:533-7.

7. O’Grady JG, Alexander GJM, Hayler KM, Williams R. Early indicators of prognosis in fulminant hepatic failure. Gastroenterology 1989; 97: 439.

8. Acharya SK, Dasarathy S, Kumar TL, Sushma S, Tandon RK, Tandon BN et al. Fulminant hepatitits in a tropical population: clinical course, cause, and early predictors of outcome. Hepatology 1996; 23: 1448.

9. Saunders SJ, Hickman R, MacDonald R, Terblanche J. The treatment of acute liver failure. In: Popper H, Schaffner F, editors. Progress in liver disease. New York: Grune and Stratton, 1970; 33-4.

10. Aggarwal R, Naik SR. Epidemiology hepatitis E Part, Present \& future. Top Gastroenterol 1997; 18: 19.

11. Mathiesen LR, Shinoj P, Nielson JO et al. Hepatitis B and non-A, non-B in fulminant hepatitis. Gut 1980; 21: 72.

12. Hytiroglou P, Dash S, Haruna Y, Fernandaz M, Theise ND, Schwartz M, et al. Detection of hepatitis B and hepatitis $\mathrm{C}$ viral sequence in fulminant hepatic failure of unknown etiology. Am J Clin Pathol 1995; 104-588.

13. Andressen M, Arrese M, Dussaillant G, Dougnac A, Compusano C, Glasinovic JC. Multiple organ failure syndrome in fulminant hepatic failure. Rev Med Chil 1994; 122: 661 .

14. Rezende G. Atonso AMR, Samuel D, Gigou M, Nicand E, Ferre V et al. Viral \& Clinical factors associated with the fulminant course of hepatitis A infection. Hepatology 2003; 38(3): 613-618.

15. Lee WM. Acute liver failure. Am J Med 1994; 96(Suppl): S3.

16. Khan M, Dhar SC, Rahmatullah M, Jahir M. Fulminant hepatic failure: aetiology, clinical options. J Inst Postgrad Med Res 1993; 8:7. 